\title{
Codeine accumulation and elimination in larvae, pupae, and imago of the blowfly Lucilia sericata and effects on its development
}

\author{
Hicham Kharbouche • Marc Augsburger • \\ Daniel Cherix • Frank Sporkert • Christian Giroud • \\ Claude Wyss • Christophe Champod • Patrice Mangin
}

Received: 13 June 2007 / Accepted: 26 October 2007 /Published online: 7 December 2007

(C) Springer-Verlag 2007

\begin{abstract}
The aim of this study was to evaluate the reliability of insect larvae as samples for toxicological investigations. For this purpose, larvae of Lucilia sericata were reared on samples of minced pig liver treated with different concentrations of codeine: therapeutic, toxic, and potentially lethal doses. Codeine was detected in all tested larvae, confirming the reliability of these specimens for qualitative toxicology analysis. Furthermore, concentrations measured in larvae were correlated with levels in liver tissue. These observations bring new elements regarding the potential use of opiates concentrations in larvae for estimation of drug levels in human tissues. Morphine and norcodeine, two codeine metabolites, have been also detected at different concentrations depending on the concentration of codeine in pig liver and depending on the substance itself. The effects of codeine on the
\end{abstract}

H. Kharbouche $(\bowtie) \cdot$ M. Augsburger $\cdot$ F. Sporkert $\cdot$ C. Giroud $\cdot$

P. Mangin

Institut Universitaire de Médecine Légale,

Centre Hospitalier Universitaire Vaudois and

University of Lausanne, rue du Bugnon 21,

CH-1005 Lausanne, Switzerland

e-mail: Hicham.Kharbouche@chuv.ch

C. Champod

Ecole des Sciences Criminelles, Faculté de Droit,

Université de Lausanne, CH-1015 Lausanne, Switzerland

D. Cherix

Département d'Ecologie et d'Evolution,

Faculté de biologie et médecine,

Université de Lausanne, CH-1015 Lausanne,

Switzerland

D. Cherix $\cdot$ C. Wyss

Musée de zoologie, Palais de Rumine,

CH-1014 Lausanne, Switzerland development of $L$. sericata were also investigated. Results showed that a 29-h interval bias on the evaluation of the larval stage duration calculated from the larvae weight has to be considered if codeine was present in the larvae substrate. Similarly, a $21-\mathrm{h}$ interval bias on the total duration of development, from egg to imago, has to be considered if codeine was present in the larvae substrate.

Keywords Entomotoxicology $\cdot$ Lucilia sericata $\cdot$ Opiates · Post-mortem interval

\section{Introduction}

The use of necrophagous insects as qualitative specimens of evidence for drug detection is well documented and largely accepted. In addition, insect colonization patterns are the most common factors utilized for post-mortem interval (PMI) estimation, especially when the discovery of the corpse is delayed and the soft tissues are decomposed. Diptera larvae feed on decomposed tissues, which may contain xenobiotics because of antemortem drug exposure. The analysis of larvae found in cadavers can, therefore, contribute to the qualitative identification of drugs present in the corpse $[1,2,3,4,5]$. In addition, drugs in putrefied tissues may have an influence on the development of the necrophagous Diptera that can affect the estimation of the PMI $[6,7,8,9,10,11]$. Drug levels in larvae could also be correlated to drug concentrations in tissues eaten by the insects, providing valuable information to elucidate the cause of death. However, the use of necrophagous species as quantitative samples is not unanimously accepted. Some authors have established a correlation between the drug concentration in the substrate and the concentration 
measured in larvae $[4,12]$. Others disagree saying that such a correlation cannot be made. The larvae behavior toward several substances is unsure; consequently, their use for quantitative analysis is strongly limited $[13,14]$.

Codeine is a psychoactive alkaloid obtained from the opium poppy (Papaver somniferum). It is especially used in therapeutics for its analgesic and antitussive properties [15]. Because it is an over-the-counter and a psychoactive substance, it is often abused as a substitute of heroine [16, 17]. Codeine can be found in fatal cases as a result of drug intoxication after accidental or criminal administration.

Our aim was to study the accumulation of codeine by larvae, pupae, and imagos. Furthermore, the two main codeine metabolites (norcodeine and morphine) were determined in the insect and in the liver feed, and their concentrations were compared. Correlation between the quantity of drug present in the substrate and the amount found in the larvae were also investigated. Finally, the effect of codeine on the development of larvae is assessed and the consequences on the evaluation of the PMI are discussed.

\section{Materials and methods}

\section{Reagents}

Codeine phosphate powder used for spiked substrate was obtained from Siegfried, Zofingen, Switzerland. Reference standards, codeine, morphine, norcodeine, and codeine- $\mathrm{d}_{3}$ (I.S.), were obtained from Lipomed, Arlesheim, Switzerland, and norcodeine-d $\mathrm{d}_{3}$ (I.S.) from Cerillant, Round Rock, TX, USA. All chemicals were of the highest analytical grade. Sodium chloride, di-sodium hydrogen phosphate, $n$ heptane, and hydrochloridric acid were purchased from Merck, Darmstadt, Germany. Chloroform, isopropanol, methanol, ammonium formate, and formic acid were from Fluka, Buchs, Switzerland.

\section{Breeding}

The eggs of $L$. sericata used in this study were kindly provided by Novartis Santé Animale S.A., St. Aubin, Switzerland. Approximately 400 eggs of $L$. sericata were deposited on different substrates constituted with homogenized tissues of pig liver $(250 \mathrm{~g})$. Each pig liver homogenate was spiked with $20 \mathrm{ml}$ physiological $\mathrm{NaCl}$ solution $(0.9 \%)$ containing different codeine concentrations $\left(\mathrm{C}_{0}, 0 \mathrm{mg} / \mathrm{kg} ; \mathrm{C}_{1}\right.$, $0.05 \mathrm{mg} / \mathrm{kg} ; \mathrm{C}_{2}, 0.25 \mathrm{mg} / \mathrm{kg} ; \mathrm{C}_{3}, 2.0 \mathrm{mg} / \mathrm{kg} ; \mathrm{C}_{4}, 30 \mathrm{mg} / \mathrm{kg}$ ) and mixed in a Waring blender for $5 \mathrm{~min}$ at room temperature. Each rearing was placed in one plastic box $(9 \times 28 \times 6 \mathrm{~cm})$ containing sawdust, which permitted the absorption of odors. This box was then placed in another plastic box $(22 \times 33 \times 9.5 \mathrm{~cm})$ containing sand to prevent adherence of the larvae to the plastic and to avoid escape. During the study, the box was maintained in an airconditioned room where the temperature was kept constant at $20^{\circ} \mathrm{C}$. The rearing was submitted to an artificial day/night rhythm from 7 to $22 \mathrm{~h}$ and from 22 to $7 \mathrm{~h}$. The cycle was related to the estival natural rhythm.

\section{Sampling}

At regular time intervals (from $t=24$ to $96 \mathrm{~h}$, every $12 \mathrm{~h}$ ), ten larvae were randomly collected from each liver sample. They were copiously washed with deionized water, dried with a filter paper, and then frozen at $-20^{\circ} \mathrm{C}$ (approximately $5 \mathrm{~min}$ ) before being weighed. The mean weight of each sample of these ten larvae was used to establish the growth curves (fresh weight vs time). Pupae and imagos were also sampled and measured. The durations of each stage were carefully recorded during development. For toxicological analysis, about $500 \mathrm{mg}$ of pig liver were also taken at $t=48$ and $60 \mathrm{~h}$ and stored at $-20^{\circ} \mathrm{C}$ until analysis. Then, approximately $500 \mathrm{mg}$ of larvae were also taken (from $t=$ 60 to $96 \mathrm{~h}$, every $12 \mathrm{~h}$ ), first washed with deionized water, and followed by a second wash with physiological $\mathrm{NaCl}$ solution $(0.9 \%)$. They were killed by freezing to $-20^{\circ} \mathrm{C}$ and stored at this temperature until analysis. Pupae and imago were treated in the same manner. The empty pupae were harvested after the appearance of the flies and finally stored at $-20^{\circ} \mathrm{C}$ until analysis.

\section{Data analysis}

Data were analyzed using analysis of variance (ANOVA) and Student's $t$ test. Calculations were carried out using Microsoft Excel 2003.

\section{Procedure of extraction}

A modified procedure was used to extract codeine and metabolites from tissues [3]. Approximately $500 \mathrm{mg}$ of larvae, pupae, imago, or liver were homogenized in a $9 \%$ $\mathrm{NaCl}$ solution $(2 \mathrm{ml})$ with an Ultra-Turrax: Janke \& Kunkel, Staufen, Germany, $2 \mathrm{ml}$ phosphate buffer $\left(\mathrm{Na}_{2} \mathrm{HPO}_{4} 0.28 \mathrm{M}\right.$ adjusted to $\mathrm{pH} 9.2$ with $\mathrm{NaOH}), 10 \mu \mathrm{l}$ of an internal standard mixture (morphine- $\mathrm{d}_{3}$ and codeine- $\mathrm{d}_{3}$ at $10 \mu \mathrm{g} / \mathrm{ml}$ ), and $10 \mathrm{ml}$ of organic extraction solvent (chloroform/isopropanol/ $n$-heptane, 50:17:33; v/v) were added. The mixture was shaken at 200 cycles/min for $10 \mathrm{~min}$ and centrifuged at $840 \times \mathrm{g}$ for $10 \mathrm{~min}$. The organic phase was removed and treated with $5 \mathrm{ml} \mathrm{HCl}(0.2 \mathrm{~N})$. A new step of agitation and centrifugation were performed in the same conditions as previously. The aqueous phase was taken, neutralized with $0.5 \mathrm{ml}$ of ammonium hydroxide solution (25\%), adjusted to 
pH 9.2 with $2 \mathrm{ml}$ phosphate buffer solution, and $5 \mathrm{ml}$ of organic extraction solvent was added. After shaking and centrifugation, the organic layer was taken, dried under $\mathrm{N}_{2}$, reconstituted in $100 \mu \mathrm{l}$ of $1 \mathrm{mM}$ formate buffer solution $\mathrm{pH} 3.0$, and $5 \mu \mathrm{l}$ extract was analyzed by liquid chromatography (LC)/mass spectrometry (MS).

\section{LC-MS analyses}

The quantification of codeine and its metabolites was carried out using a modified method previously developed for the analysis of opiates in the blood [18]. For chromatographic separation, an Inertsil ODS-3 column $(150 \times 2 \mathrm{~mm}$ I.D., Varian Chrompack; particle size, $3 \mu \mathrm{m}$ ) was used. The analyses were realized in select ion monitoring mode; the ions selected for quantification were as follows: 300.2 (codeine), 286.2 (morphine and norcodeine), 289.2 (morphine- $\mathrm{d}_{3}$ ), and 303.2 (codeine- $\left.\mathrm{d}_{3}\right)$.

\section{Validation of analytical method}

The method was validated for linearity, recovery, within and between-day precisions, limit of detection (LOD), and limit of quantification (LOQ). Calibration curves were linear between 1-500 ng/500 mg for codeine, morphine, and norcodeine with correlation coefficients $\left(r^{2}\right)$ higher than 0.99 . Recoveries were expressed as the peak area ratio (in percentage) of the corresponding amounts of extracted and non-extracted drugs injected into the LC-MS. Recoveries were determined at three concentration levels $(10,150$, and
$400 \mathrm{ng} / 500 \mathrm{mg}$ ) and were about 54 to $85 \%, 19$ to $21 \%$, and 39 to $65 \%$ for codeine, morphine, and norcodeine, respectively. The within-day $(N=5)$ and between-day precision $(N=15)$ for 10,150 , and $400 \mathrm{ng} / 500 \mathrm{mg}$ were determined by analyzing five replicates on the same day and on three different days. All coefficients of variation for the within- and between-day precisions were less than 11.9 and $18.7 \%$, respectively. The LOD was defined as the lowest concentration of the drug resulting in a signal-tonose ratio of $3: 1$. The LOD for codeine, morphine, and norcodeine were $0.5,1.0$, and $1.5 \mathrm{ng} / 500 \mathrm{mg}$, respectively. The LOQ was fixed at $5 \mathrm{ng} / 500 \mathrm{mg}$ of tissue.

\section{Results and discussion}

\section{Accumulation and elimination}

In this study, the larvae of $L$. sericata were reared on minced pig liver spiked with therapeutic, toxic, and potentially lethal concentrations of codeine for humans [19]. The breeding conditions were controlled. The larvae were then randomly collected from substrates at regular time intervals to be analyzed and the results are presented in Table 1. At each sampling time, all analyzed larvae tested positive for codeine in the $\mathrm{C}_{1^{-}}, \mathrm{C}_{2^{-}}, \mathrm{C}_{3^{-}}$, and $\mathrm{C}_{4}$-treated groups. In contrast, codeine was not detected in the larvae reared on substrates without codeine (control group). An increase of larval drug concentration was observed with increasing drug concentration in the substrate. Maximum

Table 1 Codeine, norcodeine, and morphine concentrations (ng/500 mg) measured in pig liver and in larvae, prepupae, pupae, and imago stages of $L$. sericata, reared on different substrates containing various concentrations of codeine

\begin{tabular}{|c|c|c|c|c|c|c|c|c|c|c|c|c|c|c|}
\hline \multirow[t]{2}{*}{ Time (h) } & \multirow[t]{2}{*}{ Stage } & \multicolumn{5}{|c|}{ Codeine concentrations (ng/500 mg) } & \multicolumn{4}{|c|}{$\begin{array}{l}\text { Norcodeine concentrations } \\
\text { (ng/500 mg) }\end{array}$} & \multicolumn{4}{|c|}{$\begin{array}{l}\text { Morphine concentrations } \\
(\mathrm{ng} / 500 \mathrm{mg})\end{array}$} \\
\hline & & $\mathrm{C}_{0}$ & $\mathrm{C}_{1}$ & $\mathrm{C}_{2}$ & $\mathrm{C}_{3}$ & $\mathrm{C}_{4}$ & $\mathrm{C}_{1}$ & $\mathrm{C}_{2}$ & $\mathrm{C}_{3}$ & $\mathrm{C}_{4}$ & $\mathrm{C}_{1}$ & $\mathrm{C}_{2}$ & $\mathrm{C}_{3}$ & $\mathrm{C}_{4}$ \\
\hline 48 & Liver & nd & 19.9 & 70.3 & 770.5 & 2297.2 & nd & nd & $\operatorname{tr}$ & 105.1 & $\operatorname{tr}$ & 6.7 & 39.7 & 283.1 \\
\hline 60 & & nd & 16.7 & 89.8 & 754.9 & 2170.3 & nd & $\operatorname{tr}$ & 49.3 & 429.2 & $\operatorname{tr}$ & 6.7 & 39.0 & 270.5 \\
\hline 60 & Larvae & nd & 21.5 & 22.0 & 141.6 & 474.7 & $\operatorname{tr}$ & 22.5 & 140.4 & 505.2 & nd & nd & 14.8 & 130.4 \\
\hline 72 & & nd & $\operatorname{tr}$ & 17.3 & 148.8 & 465.9 & $\operatorname{tr}$ & 16.3 & 95.0 & 446.3 & nd & $\operatorname{tr}$ & 13.2 & 86.0 \\
\hline 84 & & nd & $\operatorname{tr}$ & 13.3 & 118.2 & 383.3 & nd & 12.8 & 56.7 & 329.5 & nd & nd & 9.3 & 35.6 \\
\hline 96 & & nd & $\operatorname{tr}$ & $\operatorname{tr}$ & 77.6 & 242.1 & nd & 6.3 & 56.7 & 283.1 & nd & nd & 6.7 & 17.1 \\
\hline 108 & Prepupae & nd & nd & nd & 29.6 & 104.4 & nd & nd & 24.8 & 7.0 & nd & nd & $\operatorname{tr}$ & 2.3 \\
\hline 120 & & nd & nd & $\operatorname{tr}$ & $\operatorname{tr}$ & $\operatorname{tr}$ & nd & nd & 7.8 & 23.4 & nd & nd & $\operatorname{tr}$ & nd \\
\hline 132 & & nd & nd & $\operatorname{tr}$ & nd & $\operatorname{tr}$ & nd & nd & $\operatorname{tr}$ & 4.8 & nd & nd & nd & nd \\
\hline 150 & & nd & nd & nd & nd & $\operatorname{tr}$ & nd & nd & $\operatorname{tr}$ & 5.5 & nd & nd & nd & nd \\
\hline 174 & Pupae & nd & nd & nd & nd & $\operatorname{tr}$ & nd & nd & $\operatorname{tr}$ & 7.2 & nd & nd & nd & nd \\
\hline 192 & & nd & nd & nd & nd & $\operatorname{tr}$ & nd & nd & $\operatorname{tr}$ & 8.4 & nd & nd & nd & nd \\
\hline 288 & & nd & nd & nd & nd & nd & nd & nd & $\operatorname{tr}$ & 10.7 & nd & nd & nd & nd \\
\hline 480 & Imago & nd & nd & nd & $\operatorname{tr}$ & 23.4 & $\operatorname{tr}$ & $\operatorname{tr}$ & 6.4 & 41.8 & nd & nd & nd & $\operatorname{tr}$ \\
\hline
\end{tabular}

$\mathrm{C}_{1}=0.05 \mathrm{mg} / \mathrm{kg}, \mathrm{C}_{2}=0.25 \mathrm{mg} / \mathrm{kg}, \mathrm{C}_{3}=2.0 \mathrm{mg} / \mathrm{kg}, \mathrm{C}_{4}=30 \mathrm{mg} / \mathrm{kg}$

$n d$ Not detected, $\operatorname{tr}$ trace $(<\mathrm{LOQ}=5 \mathrm{ng} / 500 \mathrm{mg})$ 
larval concentrations were measured at $60 \mathrm{~h}$ for the $\mathrm{C}_{1}, \mathrm{C}_{2}$, and $\mathrm{C}_{4}$ groups, and at $72 \mathrm{~h}$ for larvae from the $\mathrm{C}_{3}$ group. These concentrations were different between the four groups. For each group, a fast decrease of the larvae codeine concentration was observed after $72 \mathrm{~h}$. Codeine became undetectable at $108,150,132$, and $288 \mathrm{~h}$ in the groups $\mathrm{C}_{1}, \mathrm{C}_{2}, \mathrm{C}_{3}$, and $\mathrm{C}_{4}$, respectively. In the prepupae, the concentrations of codeine were lower than those measured in larvae in the $\mathrm{C}_{3}$ and $\mathrm{C}_{4}$ groups. And, codeine was not detectable or present at trace levels in the $C_{1}$ and $\mathrm{C}_{2}$ groups $(<\mathrm{LOQ}=5 \mathrm{ng} / 500 \mathrm{mg})$. Finally, codeine was detected in the imago at $480 \mathrm{~h}$ in the $\mathrm{C}_{3}$ and $\mathrm{C}_{4}$ groups, whereas codeine was not observed at $288 \mathrm{~h}$ in the same groups.

Norcodeine was also found in the larvae reared on $\mathrm{C}_{1}$, $\mathrm{C}_{2}, \mathrm{C}_{3}$, and $\mathrm{C}_{4}$. Maximum larval concentrations were measured at $60 \mathrm{~h}$ for the three latter groups $\left(\mathrm{C}_{2}, \mathrm{C}_{3}\right.$, and $\mathrm{C}_{4}$ ). These concentrations increased with the concentration of codeine in the substrate. As in the case of codeine, a decrease of the norcodeine concentration during the first part of the growth cycle was observed. Norcodeine was not detected in the larvae of $\mathrm{C}_{1}$ group after $72 \mathrm{~h}$ and after $96 \mathrm{~h}$ in the $\mathrm{C}_{2}$ group. On the other hand, norcodeine was detectable until $288 \mathrm{~h}$ in the $\mathrm{C}_{3}$ and $\mathrm{C}_{4}$ groups. Finally, analysis of imago at $480 \mathrm{~h}$ showed the presence of norcodeine for the $\mathrm{C}_{1}, \mathrm{C}_{2}, \mathrm{C}_{3}$, and $\mathrm{C}_{4}$ groups. Noteworthy, these concentrations were higher comparing to these detected in the pupae of $\mathrm{C}_{3}$ and $\mathrm{C}_{4}$ groups. Likewise, norcodeine was detected at trace state for the $\mathrm{C}_{1}$ and $\mathrm{C}_{2}$ groups.

Morphine was only found in the larvae reared on substrates with toxic and potentially lethal concentrations of codeine. Maximum morphine concentrations were lower than maximum codeine and norcodeine concentrations. A fast elimination of morphine in larvae of the $\mathrm{C}_{3}$ and $\mathrm{C}_{4}$ groups was observed resulting in trace level $(<\mathrm{LOQ}=5 \mathrm{ng} /$ $500 \mathrm{mg}$ ) concentration even after $120 \mathrm{~h}$.

Therefore, the study of the changes in codeine concentrations with time of feeding suggests that, after 60-72 h, the elimination rate of codeine by L. sericata larvae and prepupae exceeded the rate of absorption. The analysis realized during the larval stadium revealed the presence of codeine in all the larvae analyzed. During the post-feeding stage, only the prepupae that were reared on substrate containing the highest concentrations of codeine tested positive for codeine. These measured concentrations were lower than those of the larvae. These results were in agreement with those obtained previously by Campobasso et al. [20] who reported that the elimination rate at the "inactive larvae" stage exceeded the absorption rate inducing a decrease of the opiate concentration in the larvae. Moreover, our results show that this extensive elimination is not limited at the "inactive larvae" stage but expands over the larval stage. The presence of codeine in the pupae depends on the spiked substrate amount. Only the pupae reared on substrate containing a lethal codeine concentration showed codeine concentration above the LOD. Consequently, larvae were the most appropriate samples for the toxicological analysis of codeine. Detection of codeine in the pupae might indicate a lethal level in the substrate. Furthermore, the presence of codeine in $\mathrm{C}_{3}$ and $\mathrm{C}_{4}$ samples after $480 \mathrm{~h}$ could be explained by a resumption of the food intake at the adult stage.

A better understanding of the metabolism of codeine by this Diptera should facilitate the interpretation of toxicological results. Codeine metabolites could also affect the development of the larvae in a different way. Like codeine, norcodeine was detected in the larvae of $L$. sericata. Interestingly, norcodeine was found in higher concentrations in the larvae than in the liver tissue at $60 \mathrm{~h}$ for each groups, suggesting that norcodeine persists throughout the development of $L$. sericata. Norcodeine was only found in the pupae of the insects reared on the substrates $C_{3}$ and $C_{4}$. Its detection would suggest a toxic or a lethal concentration in the substrate, indicating codeine intoxication. Likewise, norcodeine was found in higher concentrations in empty pupae than codeine or morphine.

Concerning morphine, the toxicological investigations revealed its presence in low concentrations but only in larvae reared on the substrate spiked with the highest codeine doses, i.e., $\mathrm{C}_{3}$ and $\mathrm{C}_{4}$. A rapid elimination of this molecule by the larvae of this fly was observed, in comparison to codeine and norcodeine. Moreover, morphine was not found in the empty pupae.

Codeine, norcodeine, and morphine showed different kinetics in L. sericata. The elimination of these opiates by the larvae of L. sericata could be related to their chemical structure and pharmacological properties.

The analysis of the liver used as substrate showed the presence of norcodeine and morphine at $t=48$ and $60 \mathrm{~h}$. Our results suggest that codeine was metabolized by $O-$ demethylation to morphine and by $N$-demethylation to norcodeine. These two metabolites could result from the action of liver enzymes that remain active during the first hours of autolysis [21]. The higher concentrations of norcodeine measured in larvae at $t=60 \mathrm{~h}$ in $\mathrm{C}_{1}, \mathrm{C}_{2}, \mathrm{C}_{3}$, and $\mathrm{C}_{4}$ groups suggest that norcodeine results from larvae metabolism as proposed by Pien et al. [22] and/or from a prolonged elimination of norcodeine contained in larvae.

Codeine analysis in larvae and liver

Codeine concentrations measured in the liver samples were significantly higher than those obtained in larval samples. A 
linear correlation between the spiked concentration and the larval concentration for each hour $(r>0.99)$ was observed. Despite their interest in entomotoxicology, the use of necrophagous insects by forensic experts as quantitative samples for detection of drugs remains controversial. Sadler et al. [13] have studied the accumulation and elimination of amitriptyline and nortriptyline by high-performance liquid chromatography and gas chromatography/MS. They have shown that the accumulation of drugs by the larvae of Calliphora vicina was unpredictable when they added more than one drug or various concentrations of the same drug. They considered that the larvae of Diptera were not suitable for quantitative toxicological analysis. Similarly, Tracqui et al. [14] have never supported the existence of a correlation between the drug concentration in biological tissues and those found in the larvae reared on these tissues. They found that the drug concentrations measured in the larvae collected at distinctive anatomical sites were different and not reproducible between cases.

In the present study, we have shown that the concentration of codeine found in the larvae underestimated the concentration of codeine in the liver. Similar results were already observed with opiates by Campobasso et al. [20] and Bourel et al. [23].

This study also indicates that codeine concentrations measured in the larvae were correlated with concentrations measured in the liver on which these larvae had been grown. This correlation could be observed only at the larval stage. In agreement with this finding, Introna et al. [4] have reported a similar correlation $(r=0.79)$ by comparing the morphine concentrations found in human liver and in larvae of Calliphora vicina. Their correlation was observed during the third instar larvae. Likewise, Hédouin et al. [23] showed that morphine concentrations in the larvae at third instar of $L$. sericata were significantly correlated with concentrations measured in rabbit tissues.

Effects of codeine on the development of L. sericata

To evaluate whether codeine could alter the development of $L$. sericata and, therefore, bias the estimation of PMI, entomological methods based on the larval age determined from the larval weight or on the duration of insect development stage were used. The results (see Fig. 1 and Tables 2 and 3) showed significant differences in the mean larval weight growth curve of the larvae from $\mathrm{C}_{1}, \mathrm{C}_{2}, \mathrm{C}_{3}$, and $\mathrm{C}_{4}$ groups as compared to the control $\mathrm{C}_{0}$ group (Student's $t$ test, $t_{\mathrm{obs}} \geq t_{0.01}$ ) during the larval stage (48 to $96 \mathrm{~h})$. The larvae reared on the liver samples treated with various concentrations of codeine developed faster than the control larvae. This indicates that the presence of codeine (or its metabolites) in liver tissues stimulates the growth of $L$. weight $(\mathrm{mg})$

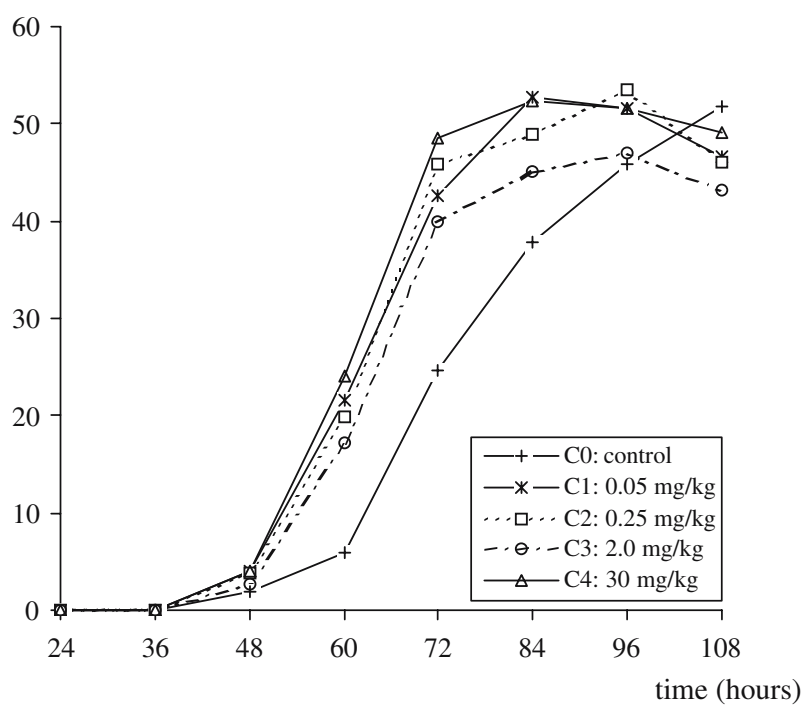

Fig. 1 Fresh weight in $\mathrm{mg}$ vs time of $L$. sericata reared on different substrates containing increasing codeine concentrations at a constant temperature of $20^{\circ} \mathrm{C}$

sericata during the larval period. The highest growth rates were observed for the $\mathrm{C}_{4}$ group. The differences between the four treated groups were not significant (Student's $t$ test, $t_{\mathrm{obs}}<$ $\left.t_{0.05}\right)$. For the tested range, codeine seems to display an "all or nothing effect" on the growth rate during the larval stage. During the pupal stage, the mean larval weights were not significantly different, suggesting that codeine does not affect the pupae development.

Therefore, regardless of the presence of codeine, the determination of larval age based on larval weight between 48 and $96 \mathrm{~h}$ could be biased. The larvae reared on the substrate of $\mathrm{C}_{4}$ group, e.g., with a lethal concentration of codeine, were observed $29 \mathrm{~h}$ before the control group. Likewise, the imagos in groups $\mathrm{C}_{1}$ and $\mathrm{C}_{4}$ were first observed $21 \mathrm{~h}$ before the control group.

According to our results and those of Goff et al. [6], codeine or morphine in tissues accelerate the development of L. sericata and of Boettchersica peregrina, respectively, whereas the presence of morphine appears to retard the growth rate for $L$. sericata during the larval stage [9]. A same species could react differently toward two molecules belong to the same family.

\section{Conclusions}

In case of death investigations, all available materials (e. g., human tissues and entomological specimens) must be considered for toxicological analysis. This is particularly true when tissues or biological fluids are in advanced 
Table 2 Fresh weight in $\mathrm{mg}$ ( \pm standard deviation for ten larvae) vs time of $L$. sericata reared on different substrates containing various concentrations of codeine with a temperature fixed at $20^{\circ} \mathrm{C}$

\begin{tabular}{|c|c|c|c|c|c|c|c|c|c|c|}
\hline \multirow{2}{*}{$\begin{array}{l}\text { Time (h) } \\
48\end{array}$} & \multicolumn{2}{|c|}{$\mathrm{C}_{0} \pm \mathrm{SD}$ (control) } & \multicolumn{2}{|c|}{$\mathrm{C}_{1} \pm \mathrm{SD}(0.05 \mathrm{mg} / \mathrm{kg})$} & \multicolumn{2}{|c|}{$\mathrm{C}_{2} \pm \mathrm{SD}(0.25 \mathrm{mg} / \mathrm{kg})$} & \multicolumn{2}{|c|}{$\mathrm{C}_{3} \pm \mathrm{SD}(2.0 \mathrm{mg} / \mathrm{kg})$} & \multicolumn{2}{|c|}{$\mathrm{C}_{4} \pm \mathrm{SD}(30 \mathrm{mg} / \mathrm{kg})$} \\
\hline & 1.9 & 0.2 & 4.0 & 0.7 & 3.9 & 0.6 & 2.7 & 0.6 & 4.0 & 0.6 \\
\hline 60 & 5.8 & 0.8 & 21.5 & 2.7 & 19.9 & 3.2 & 17.3 & 2.6 & 24.0 & 3.6 \\
\hline 72 & 24.6 & 3.4 & 42.6 & 4.5 & 45.9 & 3.6 & 39.9 & 2.8 & 48.5 & 5.4 \\
\hline 84 & 37.8 & 4.2 & 52.8 & 3.7 & 48.9 & 5.0 & 45.1 & 3.4 & 52.3 & 4.9 \\
\hline 96 & 45.9 & 3.9 & 51.6 & 2.6 & 53.5 & 5.3 & 47.1 & 3.5 & 51.5 & 5.4 \\
\hline 108 & 51.9 & 5.3 & 46.7 & 2.0 & 46.1 & 2.9 & 43.1 & 3.7 & 49.1 & 4.7 \\
\hline 120 & 41.5 & 3.9 & 45.1 & 5.6 & 43.4 & 4.9 & 38.4 & 4.0 & 44.9 & 3.8 \\
\hline 132 & 38.6 & 2.2 & 43.7 & 1.6 & 41.4 & 4.5 & 37.0 & 4.2 & 43.2 & 2.2 \\
\hline 150 & 36.0 & 3.8 & 38.8 & 3.9 & 41.9 & 2.5 & 35.6 & 2.9 & 37.1 & 2.9 \\
\hline 174 & 32.5 & 2.0 & 37.3 & 4.0 & 38.1 & 2.6 & 32.4 & 3.8 & 35.7 & 4.1 \\
\hline 192 & 36.7 & 2.1 & 37.2 & 3.7 & 39.2 & 2.9 & 36.5 & 2.7 & 38.6 & 4.4 \\
\hline 216 & 32.1 & 1.9 & 39.0 & 1.4 & 37.9 & 1.9 & 32.7 & 3.1 & 39.0 & 1.7 \\
\hline 240 & 33.9 & 4.4 & 37.2 & 2.3 & 36.2 & 1.6 & 33.5 & 2.4 & 37.7 & 2.0 \\
\hline 264 & 31.8 & 2.8 & 34.6 & 2.7 & 33.8 & 2.8 & 32.2 & 2.6 & 34.9 & 5.0 \\
\hline 288 & 33.1 & 3.0 & 35.4 & 2.1 & 33.3 & 2.9 & 32.5 & 2.2 & 35.5 & 2.5 \\
\hline 312 & 31.8 & 2.7 & 33.1 & 3.8 & 31.9 & 3.2 & 32.5 & 3.9 & 30.4 & 2.7 \\
\hline 336 & 31.0 & 3.6 & 34.2 & 2.9 & 32.5 & 3.8 & 32.7 & 2.3 & 31.9 & 2.1 \\
\hline 360 & 32.5 & 1.9 & 31.9 & 3.3 & 31.5 & 3.1 & 31.4 & 5.5 & 32.5 & 2.3 \\
\hline 384 & 29.7 & 2.1 & 31.6 & 4.1 & 32.6 & 3.8 & 30.9 & 4.7 & 32.2 & 3.8 \\
\hline 408 & 29.3 & 2.8 & 30.2 & 2.7 & 31.1 & 3.3 & 29.0 & 3.1 & 31.6 & 3.4 \\
\hline 480 & 21.5 & 3.7 & 24.5 & 1.7 & 24.1 & 1.6 & 22.1 & 0.9 & 26.2 & 2.7 \\
\hline
\end{tabular}

decomposition. Toxicological analysis are strongly disordered using putrefactive tissues or fluids. Extraction recoveries, chromatographic performances, and separations, as well as ionization efficiencies, are often significantly disturbed. As a result, drugs become hardly detectable. Moreover, the stability of drugs in post-mortem tissues is strongly diminished [24, 25]. During a comparative study, Kintz et al. [1] obtained greater sensitivity using fly larvae, living material, instead of putrefied material.

In this present study, the larvae of $L$. sericata were reared on liver tissues spiked with codeine at concentrations typical of those found after administration of therapeutic, toxic, or potentially lethal doses in humans. Codeine could be detected in all larvae, indicating that the entomological specimens are suitable for opiates investigations. Morphine and norcodeine were also detected. Norcodeine was found in higher levels than morphine and their concentrations were influenced by the level of codeine in the liver on which larvae were reared. This correlation was only observable for the active larval stage. Finally, results showed that a 29-h interval bias on the evaluation of the larval stage duration determined from the larvae weight growth curve has to be considered if codeine was present in the larvae substrate. A 21-h interval bias on the total duration of development, from egg to imago, has to be considered if codeine was present in the larvae substrate. These results indicate that the estimate of PMI can be significantly affected by the presence of xenobiotics in the larval feed.
Our study brings new elements on the correlation between the amount of codeine in the substrate and concentration of codeine in larvae of $L$. sericata, and also on the evolution of the concentration of codeine and its metabolites over the time. Analysis of larvae of L. sericata could give additional clues as regards to the opiates involved in the case of death. At last, the origin of the codeine metabolites could not be clearly elucidated, and further experiments are needed to confirm whether the larvae of $L$. sericata are able to metabolize codeine into norcodeine and/or morphine.

Table 3 Development time of L. sericata at $20^{\circ} \mathrm{C}$ under several concentrations of codeine

\begin{tabular}{lllll}
\hline Breeding & $\begin{array}{l}\text { Duration } \\
\text { of larval } \\
\text { stage (h) }\end{array}$ & $\begin{array}{l}\text { Total } \\
\text { duration of } \\
\text { development } \\
\text { (h) }\end{array}$ & $\begin{array}{l}\text { Total } \\
\text { days }\end{array}$ & $\begin{array}{l}\text { Sum of effective } \\
\text { temperatures } \\
\text { between egg and } \\
\text { imago stage }\end{array}$ \\
\hline $\mathrm{C}_{0}($ control $)$ & 177 & 459 & 19.1 & 210.4 \\
$\mathrm{C}_{1}(0.05 \mathrm{mg} / \mathrm{kg})$ & 153 & 438 & 18.3 & 200.8 \\
$\mathrm{C}_{2}(0.25 \mathrm{mg} / \mathrm{kg})$ & 155 & 442 & 18.4 & 202.6 \\
$\mathrm{C}_{3}(2.0 \mathrm{mg} / \mathrm{kg})$ & 167 & 450 & 18.8 & 206.3 \\
$\mathrm{C}_{4}(30 \mathrm{mg} / \mathrm{kg})$ & 152 & 438 & 18.3 & 200.8 \\
\hline
\end{tabular}

The effective temperature corresponds to the difference between the daily average and the temperature threshold, below which, the larvae does not develop. For L. sericata, this threshold temperature is $9^{\circ} \mathrm{C}$ (calculated according to the Marchenko method [26]). 
Acknowledgment The authors thank J. Bouvier, Novartis Santé Animale S.A, St. Aubin, Switzerland, for providing the eggs of $L$. sericata.

\section{References}

1. Kintz P, Godelar B, Tracqui A, Mangin P, Lugnier AA, Chaumont AJ (1990a) Fly larvae: a new toxicological method of investigation in forensic medicine. J Forensic Sci 35:204-207

2. Kintz P, Tracqui A, Mangin P (1990b) Toxicology and fly larvae on a putrefied cadaver. J Forensic Sci Soc 30:243-246

3. Kintz P, Tracqui A, Mangin P (1994) Analysis of opiates in fly larvae sampled on a putrefied cadaver. J Forensic Sci Soc 34:95-97

4. Introna F, Lo Dico C, Caplan YH, Smialek JE (1990) Opiate analysis in cadaveric blowfly larvae as an indicator of narcotic intoxication. J Forensic Sci 35:118-122

5. Nolte KB, Pinder RD, Lord WD (1992) Insect larvae used to detect cocaine poisoning in a decomposed body. J Forensic Sci 37:1179-1185

6. Goff ML, Brown WA, Hewadikaram KA, Omori AI (1991) Effect of heroin in decomposing tissues on the development rate of Boettcherisca peregrina (Diptera, Sarcophagidae) and implications of this effect on estimation of postmortem intervals using arthropod development patterns. J Forensic Sci 36:537-542

7. Goff ML, Brown WA, Omori AI (1992) Preliminary observations of the effect of methamphetamine in decomposing tissues on the development of Parasarcophaga ruficornis (Diptera: Sarcophagidae) and implications of this effect on the estimations of postmortem intervals. J Forensic Sci 37:867-872

8. Goff ML, Brown WA, Omori AI, LaPointe DA (1993) Preliminary observations of the effects of amitriptyline in decomposing tissues on the development of Parasarcophaga ruficornis (Diptera: Sarcophagidae) and implications of this effect to estimation of postmortem interval. J Forensic Sci 38:316-322

9. Bourel B, Hédouin V, Martin-Bouyer L, Bécart A, Tournel G, Deveaux M, Gosset D (1999) Effects of morphine in decomposing bodies on the development of Lucilia sericata (Diptera: Calliphoridae). J Forensic Sci 44:354-358

10. Carvalho LML, Linhares AX, Trigo JR (2001) Determination of drug levels and the effect of diazepam on the growth of necrophagous flies of forensic importance in southeastern Brazil. Forensic Sci Int 120:140-144

11. O'Brien C, Turner B (2004) Impact of paracetamol on Calliphora vicina larval development. Int J Legal Med 118:188-189

12. Kintz P, Tracqui A, Ludes B et al (1990c) Fly larvae and their relevance in forensic toxicology. Am J Forensic Med Pathol 11:63-65
13. Sadler DW, Richardson J, Haigh S, Bruce G, Pounder DJ (1997) Amitriptyline accumulation and elimination in Calliphora vicina larvae. Am J Forensic Med Pathol 18:397-403

14. Tracqui A, Keyser-Tracqui C, Kintz P, Ludes B (2004) Entomotoxicology for the forensic toxicologist: much ado about nothing? Int J Legal Med 118:194-196

15. Maurer HH, Sauer C, Theobald DS (2006) Toxicokinetics of drugs of abuse: current knowledge of the isoenzymes involved in the human metabolism of tetrahydrocannabinol, cocaine, heroin, morphine, and codeine. Ther Drug Monit 28:447-453

16. Jensen S, Hansen AC (1993) Abuse of codeine separated from over-the-counter drugs containing acetylsalicylic acid and codeine. Int J Legal Med 105:279-281

17. Kintz P, Tracqui A, Mangin P (1991) Codeine concentrations in human samples in a case of fatal ingestion. Int $\mathrm{J}$ Legal Med 104:177-178

18. Dienes-Nagy A, Rivier L, Giroud C, Augsburger M, Mangin P (1999) Method for quantification of morphine and its 3- and 6glucuronides, codeine, codeine glucuronide and 6-monoacetylmorphine in human blood by liquid chromatography-electrospray mass spectrometry for routine analysis in forensic toxicology. $\mathrm{J}$ Chromatogr A 854:109-118

19. Baselt RC (2004) Disposition of toxic drugs and chemicals in man, 7th edn. Biomedical Publications, Foster City, pp pp 212-213

20. Campobasso CP, Gherardi M, Caligara M, Sironi L, Introna $\mathrm{F}$ (2004) Drug analysis in blowfly larvae and in human tissues: a comparative study. Int J Legal Med 118:210-214

21. Yamazaki M, Wakasugi C (1994) Postmortem changes in drugmetabolizing enzymes of rat liver microsome. Forensic Sci Int 67:155-168

22. Pien K, Laloup M, Pipeleers-Marichal M et al (2004) Toxicological data and growth characteristics of single postfeeding larvae and puparia of Calliphora vicina (Diptera: Calliphoridae) obtained from a controlled nordiazepam study. Int J Legal Med 118:190-193

23. Hédouin V, Bourel B, Martin-Bouyer L et al (1999) Determination of drug levels in larvae of Lucilia sericata (Diptera: Calliphoridae) reared on rabbit carcasses containing morphine. J Forensic Sci 44:351-353

24. Skopp G, Pötsch L, Klingmann A, Mattern R (2001) Stability of morphine, morphine-3-glucuronide, and morphine-6-glucuronide in fresh blood and plasma and postmortem blood samples. J Anal Toxicol 25:2-7

25. Schloegl H, Dresen S, Spaczynski K, Stoertzel M, Wurst FM, Weinmann W (2006) Stability of ethyl glucuronide in urine, postmortem tissue and blood samples. Int J Legal Med 120:83-88

26. Marchenko MI (2001) Medico-legal relevance of cadaver entomofauna for the determination of the time since death. Forensic Sci Int 120:89-109 